\title{
Measures and Reflection on Discipline Construction in Colleges and Universities-taking Tianjin as example
}

\author{
Xin Wang ${ }^{1, a}$,Xiao Fan Zhang ${ }^{2, b}$ \\ ${ }^{1}$ Tianjin University of Finance and Economics Business School Department of Management \\ Science and Engineering,Tianjin,300222, China \\ ${ }^{2}$ Tianjin University of Finance and Economics Dean's Office, Tianjin,300222, China \\ awangppxin@163.com, ${ }^{\mathrm{b}}$ 53904593@qq.com
}

Keywords: Government; Colleges and universities; Discipline construction; Development

\begin{abstract}
In the process of rapid development of discipline construction in colleges and universities, the government plays an extremely important role, and expenditure guarantee, resource configuration, arrangement adjustment and so on are closely related to macro regulation of government; in order to improve high level talents cultivation and serve social construction, the government needs to increase investment in discipline construction and make guidance over overall development, investment planning of colleges and universities, and proposes suggestions after assessment and inspection over practical effect and development scheduling of discipline construction in colleges and universities. The government should establish discipline with pertinence and invest in it based on its own developmental plan and need, striving for cultivating high level talents conforming to developmental demand. As a result, in the developmental process of discipline construction in colleges and universities, the effect of government can not be ignored. The effective promotion of discipline construction in colleges and universities by the government, referring to the pattern research on government's promotion about discipline construction in colleges and universities is significant.
\end{abstract}

\section{General situation of development in discipline construction in colleges and universities promoted by Tianjin government}

Brief process of discipline construction in colleges and universities in Tianjin. Investment construction in Ninth five years plan. Tianjin Board of Education, Tianjin Financial Bureau invest 0.1 billion RMB with focus on construction and renovation of basic teaching laboratory and improvement of comprehensive school running ability in colleges and universities of Tianjin, solving bottleneck problems in basic school running brought about by enrollment increase in colleges and universities.

Municipal significant discipline construction in first phase and second phase.Continue new idea of key discipline construction in our city; confirm important status of discipline construction; drive overall improvement in educational level of colleges and universities in the city with common development of multiple brand disciplines; create profound academic atmosphere; pay attention to necessity of discipline construction fundamentally.

Municipal key discipline construction in first phase.In 1993, board of education approved 64 disciplines as key disciplines in the first phase in Tianjin, including 38 disciplines in ministry and commission institutions, 26 disciplines in municipal colleges and universities, with municipal financial investment of 20 million RMB mainly used in construction of 26 disciplines in municipal colleges and universities.

Municipal key discipline construction in second phase .In 2000, municipal board of education started and selected construction of 16 municipal key disciplines in second phase among ten colleges and universities in cit after expert review based on municipal key discipline construction in first phase. The construction period of second phase municipal key disciplines is 4 years from 2000.1.1 to 
2003.12.31 with special municipal financial investment being 13.40 million RMB, of which the mating investment in municipal colleges and universities is in the proportion of 1: 0.5 , and the mating investment in subordinate colleges and institutions is in the proportion of 1:1, finally total expenditure in discipline construction being 80.64 million RMB. In 2002, municipal board of education made middle term inspection and promotion as to key disciplines in second phase. In July, 2004, municipal board of education, financial bureau organized experts to make acceptance about key discipline construction in second phase.

Professional construction of planned disciplines with comprehensive investment of fifth five years plan in colleges and universities. Transfer and promote laboratory investment in ninth five years plan to professional discipline construction with investment focus on supporting construction of high level scientific and research, school-running platform. Formulate fifth five years comprehensive investment plan implementation scheme in colleges and universities of Tianjin. Establish professional discipline construction project with confirmation about 49 key disciplines for construction (all belongs to municipal key disciplines) based on overall requirement of implementation scheme. From 2001 to 2005, municipal financial bureau and board of education integrated 0.8 billion of expenditure and made expenditure investment based on plan. 49 disciplines have finished acceptance.

Three construction emphasis in eleventh five years plan.During period of eleventh five years plan, three construction emphasis was made including innovative platform construction, innovative team construction, and innovative mechanism construction, of which the government invested 1.4 billion RMB in discipline construction with 58 key municipal disciplines in colleges and universities, at the meantime bringing about a batch of undergraduate professional construction. At the meantime, 21 extremely essential disciplines were started for construction with coordination with starting of 150 municipal undergraduate brand professional constructions by quality project of board of education, emphasizing in equipping with a batch of professional laboratories and scientific research laboratories.

Discipline construction in colleges and universities in Tianjin during twelfth five years plan. After three previous discipline construction investments in Tianjin, the government has gained certain effect from new service idea and macro promotion policies. As a result, during the period of twelfth five years plan, the government continues to play the role of director and establish service idea, integrate resources with emphasis in investment, as well as provide for colleges and universities with sufficient autonomous right, making discipline construction development healthily and creating three kinds of disciplines.

Leading preponderant discipline.This kind of discipline possesses strong subject sedimentary deposits with obvious advantages, outstanding features, whose overall level ranks first among the same kind of domestic discipline, and whose construction target and task can be understood as: maintain or add newly national (or ministry level) key laboratory, engineering center (humanistic base), and create domestic first-rate scientific and research platform; maintain or add newly national (or ministry level) innovative team, and gather high level talents (Yangtze River, outstanding youth, thousands of people plan and so on), create domestic first-rate scientific and research team, and cultivate top innovative talents and leading talents in discipline; the strategy of serving country undertakes national significant scientific and research projects and cultivates high level innovative achievements; play an significant role in aspects of serving local economic construction and social construction, wining landmark achievements.

Featured preponderant discipline. This kind of discipline generally possesses excellent discipline construction basis, being closely related to local economic and social development in Tianjin with obvious application features, which is able to play an important role in promoting scientific and technological innovation in related industries.

Strategic developmental discipline. This kind of discipline can be called third type of discipline, generally possessing certain comparative advantages in the same discipline of Tianjin, which is able 
to be connected with local pillar industry and strategic newly emerging industry through integration and renovation as well as adjustment, and is able to bring about development in related discipline, becoming scientific power of local industry and pillar industry development.

\section{Measures of Tianjin government to promote discipline construction in colleges and universities}

It is found in practical analysis on Tianjin government's promotion over discipline construction in colleges and universities that the government promotes discipline construction in colleges and universities from macroscopic perspective. There is inevitably some problems existing in the developmental process, which brings about some negative influence on discipline construction in colleges and universities more or less, needing a series of reasonable policies' promotion for effective realization. The following measures favorable to promote discipline construction are proposed combined with above contents.

Put democratic rights of colleges and universities into practice. Put democratic rights of colleges and universities into practice and improve autonomous right and increase developmental space, ensuring that the discipline construction in colleges and universities can be conducted based on its own developmental rules free from influence brought about by administration. Promote democratic management, manage school by law, and work by regulations; improve system framework, supervision mechanism, and form excellent developmental atmosphere. Increase connection between colleges and universities with society with combination between production and study, with the purpose to realize excellent interaction between society and colleges and universities.

Establish perfect legal institutions. Establish perfect legal mechanism, reduce as much as possible unfavorable factors brought about by government' s intervention into discipline construction; standardize government behaviors with definite and fair laws with evidence, reducing casualty of government's intervention, as well as making clear about autonomous rights enjoyed by colleges and universities in the process of discipline construction, thus standardizing and coordinating relationship between the two, defining border of two, reducing occurrence of disadvantages. Finally, the discipline construction in colleges and universities will activate more enthusiasm with guarantee over behaviors.

Establish effective macro-control mechanism. Establish a series of effective macro-control mechanism, which can be regarded as effective channels. The specific practice can be manifested in the following points:

First, make plan. In order to promote discipline construction effectively, the government must combine with practical needs of social development, find momentums from internal core of discipline development based on scientific rules, make further practical investigation, and then the government organizes negotiation in each aspect with manifestation of its will, and compiles overall development plan with clear level positioning, automatic positioning development, which is favorable to intensified, constant, further and comprehensive construction of discipline.

Secondly, make capital allocation. The discipline development in colleges and universities can not live without materials support provided by the government. Sufficient material as basis and formulation of effective and fair capital allocation system can guide excellent discipline development.

Thirdly, make supervision. Manifest requirement of government function and macro control, and promote establishment of talent cultivation system. Assessment promotes scientific monitoring mechanism, meaning that scientific supervision mechanism can promote better development of discipline in colleges and universities. Of course, the government can make supervision, so can colleges, and universities with self-supervision and self-adjustment. The government should make sufficient researches on standard supervision scheme and organize related experts to make special supervision and assessment about process, capital use, and implementation of targets and tasks and so on, with emphasis on process management, responsibility implementation, and increase in capital 
use efficiency as well as accomplishment of all kinds of targets. Implement strictly process management and performance assessment mechanism.

Fourthly, make information guidance. The key of success of colleges and universities lies in their own features. Only if you have features different from other colleges and universities, the feature can become core competitiveness no matter the difference in school running time, recruitment scale, job export and so on, which can guide you to develop towards higher level, becoming successful.

Fifthly, implement expert consultation guarantee mechanism. Establish expert argumentation, consultation, evaluation system. Be in charge of consultation and argumentation about investment planning, tracking and guidance of investment project implementation, participation in checking and acceptance, performance assessment and so on.

Sixthly, make trail school reform. Establish education and teaching reform trail area centering on innovative talent cultivation system, promote trail college reform, adopt special policies, reform talent recruitment and selection mode, reform talent cultivation pattern, reform teacher selection, assessment and evaluation system, improve internal governance structure of college, finally realizing new breakthrough in talent cultivation and college management system mechanism.

Seventhly, explore and establish collaborative innovation mechanism.

\section{References}

[1] Xiaoting Fan, Maocong Zhang, Study on relation between Chinese government and universities. Zhengzhou Normal Education, 2012.12; sixth periodical, first volume. (in chinese)

[2] Fei Zheng, Effect and improvement of government function in discipline construction of colleges and universities, 2012; 278-279.(in chinese)

[3] Wei Liu , Wanhong Zhang, The relation between Chinese government and universities. Coal Higher Education, Nov, 2008, sixth periodical, 26 volume.(in chinese)

[4] Jian Liu , Macroscopic University System Evolution in England in 20C, master's thesis, Hunan Normal University, 2012.5.(in chinese)

[5] Xiao Luo, Government intervention pattern and promotion mechanism research, master's thesis, Zhejiang Polytechnic University, June, 2011.(in chinese)

[6] Steve. O., Michael. S, Leela. B, Indicators of presidential effectiveness: a study of trustees of higher education institutions, The International Journal of educational Management, 2001(6).

[7] Michael Education Shattock. Re-Balancing Modern Concepts of University Governance. Higher Quarter1y, 2002,(3) .

[8] Scott R. Istitutions and Organizations(Second Edition)[M].Thousand

Oaks· London· New Delhi: Sage Publication. 2001.

[9] Hirst,P.Democracy and Governance[A],in Pierre,J.(eds.),Debating Governance[C],New York:Oxford University Press,2000:13-35.

[10] Ulrich Teichler. Research on the relationships between higher education and The world of work: Past achievements, problems and new challengesfJ] .Higher Education, 1999(38).

[11] Steve Martin. Implementing best Value[M].Local Public Service Transition Public Administration,2000.

[12] The World Bank.China Higher Education Reform.2001. 